\title{
Localization of Immunoreactive Cholecystokinin Precursor to Amacrine Cells and Bipolar Cells of the Macaque Monkey Retina
}

\author{
David W. Marshak, ${ }^{1}$ Leslie B. Aldrich, ${ }^{2}$ John Del Valle, ${ }^{2}$ Tadataka Yamada ${ }^{2}$ \\ 'Department of Neurobiology and Anatomy, University of Texas Medical School, Houston, Texas 77025, and ${ }^{2}$ Department \\ of Internal Medicine, University of Michigan Medical School, Ann Arbor, Michigan 48109
}

\begin{abstract}
We used antisera that recognized precursors of the neuropeptide cholecystokinin extended at the carboxyl terminus in an immunocytochemical study of the macaque retina. $\mathbf{A}$ subpopulation of bipolar cells with long, obliquely oriented dendrites was labeled. Their axons terminated exclusively in the fifth stratum of the inner plexiform layer, where they contacted processes of amacrine and ganglion cells. Based on their morphology, these cells appeared to be the type that contacts short-wavelength cones selectively. Two types of amacrine cells were also labeled, and processes from both types formed dense plexuses in the second and fourth strata of the inner plexiform layer. The majority of their synaptic connections were with other amacrine cells, but they had more contacts with bipolar cell axons and retinal ganglion cell dendrites than any other peptidergic cells in the macaque retina.
\end{abstract}

We studied extracts of macaque retina with gel-filtration chromatography and radioimmunoassays to confirm our immunohistochemical results. We found cholecystokinin octapeptide and other immunoreactive forms that were amidated at their carboxyl termini and were therefore likely to be biologically active. Unlike most other regions of the CNS, however, the retina had relatively low concentrations of amidated forms, and forms with extended carboxyl termini that are presumably their precursors were far more abundant. These findings suggest that the rate of cholecystokinin synthesis in the retina is quite high, as we would expect if the peptide were found in tonically active neurons.

The neuropeptide cholecystokinin (CCK) has been detected by radioimmunoassays in the retinas of all vertebrate classes, and CCK immunoreactive (-IR) forms have been characterized by chromatography of retinal extracts (Osbornc ct al., 1981, 1982; Yamada et al., 1981; Eskay and Beinfeld, 1982; Aldrich et al., 1987). Like most other retinal neuropeptides, CCK-IR has been

\footnotetext{
Received Oct. 27, 1989; revised Apr. 2, 1990; accepted May 1, 1990.

We are grateful to Mr. Jeff Ellard, Ms. Claudia Gomez, and Mrs. Lillemor Krosby for technical assistancc. Wc also wish to thank Dr. John Walsh for providing antisera to gastrin and CCK, Dr. Margaret Koontz and Dr. Nobuo Kouyama for critical reviews of the manuscript, and Dr. M. L. J. Crawford and Dr. Ernst Knobil for providing some of the eye tissue used in these studies. Other eyes were provided by the Tissue Distribution Programs at the Regional Primate Research Centers at the Universities of California, Oregon, and Washington. This work was supported by Grants EY06472 and EY05205 from the National Eye Institute of NIH.

Correspondence should be addressed to David W. Marshak, Ph.D., Department of Neurobiology and Anatomy, University of Texas Medical School, P.O. Box 20708 , Houston, TX 77225.

Copyright $\odot 1990$ Society for Neuroscience $0270-6474 / 90 / 093045-11 \$ 03.00 / 0$
}

localized to amacrine cells in all vertebrates studied to date (Eriksen and Larsson, 1981; Osborne et al., 1981, 1982; Yamada et al., 1981; Brecha, 1983). In frogs, CCK-IR has also been localized to retinal ganglion cells (Kuljis et al., 1984; Kuljis and Karten, 1988). Mammals have CCK-IR neurons that branch in the outer plexiform layer (OPL), in addition to amacrine cells. CCK-IR has been localized to horizontal cells in the cat retina and to large synaptosomes that originate from the OPL in the cow retina (Osborne et al., 1981; Thier and Bolz, 1985).

CCK has also met other criteria for identifying ncurotransmitters or neuromodulators in the retina (for a review, see Osborne, 1985). In the frog eyecup preparation, pulse-chase studies have shown that CCK-IR was synthesized from a large precursor and that a smaller form resembling the amidated octapeptide (CCK8) was released (Yamada et al., 1981). Specific membrane receptors for $\mathrm{CCK}$ and related peptides have been identified in frog and toad retinas, and these were similar to the B-type CCK receptors of the brain (Bone and Rosenzweig, 1987). CCK8 applied to the retina by iontophoresis was also shown to have inhibitory effects on the spontaneous and light-evoked activity of all briskly responding types of cat retinal ganglion cells (Thier and Bolz, 1985).

The exact roles that neurons containing CCK-IR play in the neural circuits of the retina are still uncertain, however. In 2 previous studies of the localization of CCK-IR in mammalian retinas, it was mentioned that it was difficult to label these neurons with antisera to $\mathrm{CCK} 8$ or the amidated tetrapeptide (CCK4) (Eriksen and Larsson, 1981; Thier and Bolz, 1985). As a result, the morphology of neurons containing CCK-IR in mammalian retinas had not been described in detail, and there had been no previous electron-microscopic studies of the synaptic connections of retinal neurons containing CCK-IR in any species.

We were able to obtain more reliable labeling of the neurons that contain CCK with antisera directed against a synthetic peptide resembling a posttranslational processing intermediate of its precursor (proCCK), rather than with antisera against the small, covalently modified forms of CCK. We used 5 different antisera that recognized the sequence Trp-Met-Asp-Phe-Gly, which is amidated to produce the active forms of CCK (reviewed by Sugano et al., 1985). With these antisera, it was possible to study the morphology and synaptic connections of neurons containing CCK-IR in the macaque monkey retina and to propose functions for these cells in visual information processing. We also confirmed these results in biochemical studies of macaque retinal extracts.

Some of these results were described in a preliminary report (Marshak, 1989). 


\section{Materials and Methods}

Characterization of retinal peptides. Eyes from Macaca mulatta were obtained less than $30 \mathrm{~min}$ post mortem and incised approximately 4 $\mathrm{mm}$ behind the limbus. Most of the vitreous humor was removed, and the retinas were dissected free of the pigmented epithelium. The retinas were frozen and stored at $-70^{\circ} \mathrm{C}$. The frozen retinas were boiled in 10 vol distilled water for $15 \mathrm{~min}$, homogenized, boiled again for $15 \mathrm{~min}$, and centrifuged at $3000 \times \mathrm{g}$. Half the supernatant was reserved as the water extract, and an equal volume of $6 \%$ acetic acid was added to the remainder. The extract was boiled for another $15 \mathrm{~min}$ and centrifuged again; this supernatant was designated the acid extract.

Aliquots of the extracts were assayed for gastrin with antiserum 1611 , as described by Rosenquist and Walsh (1980). Calcitonin gene-related peptide (CGRP) was assayed according to Cote et al. (1987). The extracts were applied to a $1 \times 120-\mathrm{cm}$ Sephadex G50 Superfine column calibrated with $\mathrm{BSA}, \mathrm{NaCl}$, and $\mathrm{CCK} 8$. The water extract was eluted with $0.025 \mathrm{~m}$ sodium harbital huffer $(\mathrm{pH}, 8.6)$ with $1 \% \mathrm{BSA}$, and the acid extract was eluted with $0.1 \mathrm{~m}$ sodium acetate buffer $(\mathrm{pH}, 5.0)$. The extracts and column fractions were assayed for $\mathrm{CCK}$ and its posttranslational processing intermediates using procedures described previously (Rosenquist and Walsh, 1980; Sugano and Yamada, 1985; Sugano et al., 1985).

Immunocytochemical labeling. Most of the eyes for these studies were obtained from $M$. mulatta $(n=21)$, but similar results were obtained from $M$. fascicularis $(n=5)$ and $M$. nemestrina $(n=2)$. A few eyes that had been pertused with fixative by other investigators were used, but the majority were hemisected and fixed by immersion, either in this laboratory or at Regional Primate Research Centers. A 2-step fixation procedure for correlated light and electron microscopy was used most frequently. The first fixative was $4 \%$ paraformaldehyde with $0.05-0.2 \%$ glutaraldehyde in $0.1 \mathrm{~m}$ sodium phosphate buffer $(\mathrm{PB})(\mathrm{pH}, 7.2)$ for 60 min at 20 or $37^{\circ} \mathrm{C}$, and the second was $4 \%$ paraformaldehyde in $\mathrm{PB}$ $(\mathrm{pH}, 10)$ for up to $48 \mathrm{hr}$ at $4^{\circ} \mathrm{C}$. Other eyes were fixed for up to $48 \mathrm{hr}$ at $4^{\circ} \mathrm{C}$ in either picric acid formaldehyde [0.1\% picric acid, $2 \%$ paraformaldehyde, with or without $0.05 \%$ glutaraldehyde, in $\mathrm{PB}(\mathrm{pH}, 7.2)]$; PLP [0.1 м lysine, $0.01 \mathrm{M}$ sodium $m$-periodate, $2 \%$ paraformaldehyde in $\mathrm{PB}(\mathrm{pH}, 7.2)]$, or $4 \%$ paraformaldehyde in PB.

The retina was either isolated whole or sectioned at $500 \mu \mathrm{m}$ with a Brinkmann tissue chopper and labeled by a modification of the method of Eldred et al. (1983). Glutaraldehyde- or picric-acid-fixed tissue was incubated for $60 \mathrm{~min}$ in $1 \%$ sodium borohydride in PBS. The tissue was rinsed 3 times for at least 10 min each in PBS after this and all succeeding steps, and, unless otherwise noted, PBS was used as the diluent for all the reagents. The tissue was then treated for $10 \mathrm{~min}$ each with an ascending and descending series of ethanol solutions (including 10,25 , and $40 \%$ ). The tissue was incubated with antisera to the synthetic peptide Tyr-Gly-Trp-Met-Asp-Phe-Gly (G6-Gly) diluted 1:1000 for 210 days at $4^{\circ} \mathrm{C}$. These were raised against keyhole-limpet-hemocyaninconjugated peptide as described previously (Sugano et al., 1985). These antisera included 8237 and 4 others with similar characteristics: 20637 , R5B16, R6B 16, and R8B15. All these antisera recognized G6-Gly and Asp-Tyr-Met-Gly-Trp-Met-Asp-Phe-Gly (CCK-Gly) equally well at concentrations ranging from $100-500 \mathrm{fmol} / \mathrm{ml}$. They did not recognize G6-Gly-Arg-Arg or peptides such as CCK or gastrin amidated at the carboxyl terminus, even at micromolar concentrations. For control experiments, $16-\mu \mathrm{m}$ cryostat sections were used, and the antisera were preadsorbed with synthetic CCK8, G6-Gly-Arg-Arg, or G6-Gly for 60 min at $20^{\circ} \mathrm{C}$. These were labeled by an indirect immunofluorescence technique in which avidin-fluorescein isothiocyanate (FITC) (Vector) was substituted for avidin HRP in the protocol above, and the sections were viewed with a Zeiss Photomicroscope III with epifluorescent illumination.

The tissue was incubated with biotinylated goat anti-rabbit IgG (Vector) at 1:200 for 2 days and avidin-biotin peroxidase complex (Vector) at $1: 100$ for 1 day. The tissue was reacted with diaminobenzidine $(0.5$ $\mathrm{mg} / \mathrm{ml})$ and hydrogen peroxide $(0.005 \%)$ for $60 \mathrm{~min}$, treated for light microscopy with $0.1 \%$ in PBS $(10 \mathrm{~min})$ or for electron microscopy with $1 \%$ in $\mathrm{PB}$ osmium tetroxide ( $1 \mathrm{hr})$, then dehydrated and embedded in Epon. Retinas were sectioned at $20-60 \mu \mathrm{m}$ for light microscopy and photographed with a Zeiss Photomicroscope III or drawn with a camera lucida. Ultrathin sections were stained with uranyl acetate ( $2 \%$ in $50 \%$ methanol, $60 \mathrm{~min}$ ) and lead citrate $(0.2 \%$ aqueous, $1 \mathrm{~min})$, then photographed in a JEOL $100 \mathrm{CX}$ electron microscope. Bipolar cells were identified by their uniform synaptic-vesicle distribution and their characteristic synaptic ribbons. Profiles that did not contain synaptic ribbons but had unevenly distributed synaptic vesicles and other presynaptic specializations were classified as amacrine cell processes. Profiles lacking presynaptic specializations or containing rough endoplasmic reticulum were classified as retinal ganglion cell dendrites (Dowling and Boycott, 1966).

\section{Results \\ Radioimmunoassays}

Three different antisera that recognized peptides derived from the CCK or gastrin precursors were used, and the mean values in the acid and water extracts were summed to determine total immunoreactivity. The highest concentrations of peptides in retinal extracts were observed with antisera to intermediates of proCCK extended at the carboxyl terminus. Antiserum 5135, which recognized forms amidated at the carboxyl terminus, detected $2.1 \pm 0.9$ (mean $\pm \mathrm{SD}$ ) $\mathrm{pmol} / \mathrm{gm}$. Antiserum 8237 to G6-Gly detected $4.8 \pm 1.2 \mathrm{pmol} / \mathrm{gm}$ of forms with glycine remaining at the carboxyl terminus. Antiserum 8207 against G6Aly-Arg-Arg detected $11.8 \pm 3.8 \mathrm{pmol} / \mathrm{gm}$ of peptides that were further extended at the carboxyl terminus. Nothing was detected with antiserum 1611, which recognized a sequence unique to gastrin. Because progastrin is the only other precursor for this "family" of structurally related peptides in mammals, these negative results indicated that all the immunoreactive peptides detected in the retina were derived from proCCK.

\section{Gel filtration chromatography}

The elution profiles of the extracts on Sephadex G50 are illustrated in Figure 1. The largest peaks were observed in the acid extract with antiserum 8207 (Fig. 1a). There was a large peak at the position where CCK8 eluted and a oroader peak near the void volume. Antiserum 8237 (Fig. $1 b$ ) also detected a peak in the same position near the void volume of the water extract and another, somewhat smaller one centered in fractions 37 and 38 in the acid extract. Peaks at the void volume and at the CCK 8 standard were also observed with antiserum 5135 (Fig. $1 c)$.

\section{Specificity of immunolabeling}

G6-Gly antisera labeled distinct populations of amacrine and bipolar cells in the macaque retina. The labeling was completely blocked when $1 \mu \mathrm{g} \mathrm{G6-Gly} \mathrm{was} \mathrm{preincubated} \mathrm{with} 100 \mu$ ldiluted G6-Gly antisera. An equal amount of G6-Gly-Arg-Arg diminished the labeling somewhat, and the labeling was unaffected by sulfated $\mathrm{CCK} 8$ at even higher concentrations. Other antisera to $\mathrm{CCK} 4, \mathrm{CCK} 8$, or other CCK precursors gave negative or inconsistent results. The antisera did not recognize CGRP, an unrelated peptide that has been shown to cross-react with some CCK8 antisera (Williams et al., 1987). Although the assay for CGRP yielded positive results in immunoassays of macaque uveal tissues, the same antisera did not detect CGRP in extracts or sections of the macaque retina (R. F. Gagel and D. W. Marshak, unpublished observations).

\section{Labeled bipolar cells}

The bipolar cells were clearly distinguishable from the labeled amacrine cells. The bipolar cell perikarya were smaller in diameter, approximately $7-7.5 \mu \mathrm{m}$ in the midperipheral retina. In addition, the labeled bipolar cells were located more distally, either in the most proximal or in the second row of the inner nuclear layer (INL) in most animals (see Figs. 2, 3). Perikarya 


\begin{tabular}{lcll}
\hline Table 1. & Synapses of labeled bipolar cells & \\
& $\begin{array}{c}\text { Presynaptic } \\
\text { amacrine cells }\end{array}$ & $\begin{array}{l}\text { Postsynaptic } \\
\text { amacrine cells }\end{array}$ & $\begin{array}{l}\text { Postsynaptic } \\
\text { ganglion cells }\end{array}$ \\
\hline$N$ & 9 & 19 & 21 \\
$\%$ total & $18 \%$ & $39 \%$ & $43 \%$ \\
$\%$ type & - & $48 \%$ & $53 \%$
\end{tabular}

The synapses of the labeled neurons in this table are described in 3 different ways. On the first line, the absolute numbers in each category were listed $(N)$. The term "presynaptic cells" refers to the unlabeled cells that provide inputs to the labeled neurons (in this case, bipolar cells). Amacrine cells were the only cell types that were presynaptic; reciprocal and nonreciprocal synapses were not distinguished. The term "postsynaptic cells" refers to the cells that received synapses from the labeled cells (in this case, bipolar cells). The second line, "\% total," compares the number of synapses in that category to the total number of synapses made by the labeled bipolar cell axons, those where they are presynaptic and those where they are postsynaptic. The third line " \% type," compares the number in each category to either the other presynaptic cells or the other postsynaptic cells. In this case, there is nothing in the presynaptic category because amacrine cells were the only presynaptic type. Note that approximately half the postsynaptic elements were amacrine cell processes and that half were retinal ganglion cell dendrites. Generally, the bipolar cell axons made many more synapses than they received.

displaced to the outer nuclear layer $(\mathrm{ONL})$ were observed in only $1 \mathrm{M}$. mulatta in our sample (not illustrated).

There was some variability in the morphology of the labeled dendrites. Frequently, one dendrite was $1-2 \mu \mathrm{m}$ in diameter, and the others were much smaller, approximately $0.2 \mu \mathrm{m}$ in diameter. In other labeled bipolar cells, the dendrites were roughly equal in diameter (see Fig. 3). Despite these differences, all the labeled cells appeared to contact the same population of cones selectively. The cell in Figure $3 a$ is an example of the rare bipolar cells that contacted cones directly above their perikarya. The labeled dendrites typically took a long, oblique course through the OPL (see Fig. $3 b, c$ ). The dendrites typically bypassed 3 neighboring cones before they branched, formed small expansions, and terminated. In some instances, labeled cells sent 2 dendrites to the same cone (see Fig. 3c). Another indication of the selectivity of the contacts with cones was that labeled dendrites from 2 or 3 cells often converged on the same cone.

Labeled axons descended to the most proximal fifth of the inner plexiform layer (IPL), where they bifurcated. Despitc an extensive search, no axons were observed terminating in more distal strata of the IPL (see Figs. 2, 3). The synaptic connections of the labeled axons are summarized in Table 1 . The axons received inputs from unlabeled amacrine cells, but these comprised only $18 \%$ of all their synapses. The majority of the inputs to labeled cells were found at sites without synaptic ribbons like the one illustrated in Figure 4. The bipolar cell axons were presynaptic at asymmetric, ribbon synapses like the ones illustrated in Figure 4. Most of these were dyads, where 1 amacrine cell dendrite and 1 ganglion cell dendrite were postsynaptic. There were only 2 dyads that contained 2 ganglion cell dendrites and only 2 dyads with 2 amacrine cell dendrites. There were also several instances in which only 1 postsynaptic element could be identified at the ribbon synapses. As indicated in Table 1 , approximately half the output of the labeled bipolar cells was directed to amacrine cells, and half was directed to ganglion cells.

\section{Labeled amacrine cells}

Antisera to G6-Gly also labeled 2 distinct types of amacrine cells. The most common was a small, bistratified amacrine cell (see Figs. 5, 6a,b) with dendrites in 2 narrow strata centered at
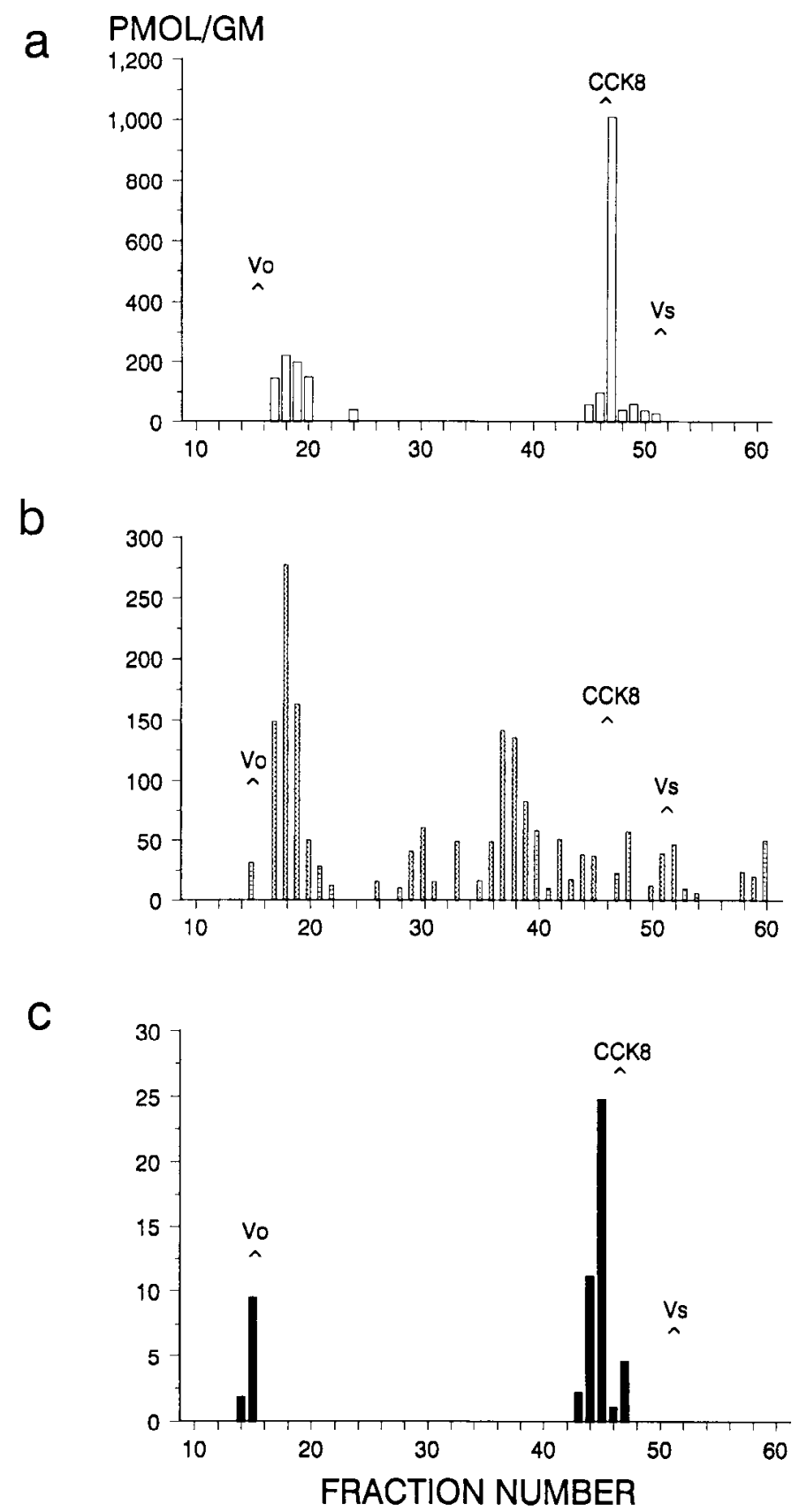

Figure 1. Chromatograms of retinal extracts. Three antisera that recognized different products of proCCK were used to analyze Sephadex G-50 chromatograms of retinal extracts. The fractions in which large proteins $(V o)$, salts $(V s)$ and CCK8 eluted are indicated above each chromatogram. $a$, Open bars indicate the forms detected with antiserum 8207 raised against G6-Gly-Arg-Arg. b. Gray bars indicate the material detected with antiserum 8237 raised against G6-Gly. c, Solid bars indicate the material detected with antiserum 5135 against CCK.

approximately $30 \%$ and $65 \%$ of the distance from the INL to the ganglion cell layer (GCL). The diameter of the perikarya ranged from $8-9 \mu \mathrm{m}$ in central retina to $10-11 \mu \mathrm{m}$ in peripheral retina. Approximately half the perikarya were found in the proximal row of the INL, and half were found in the GCL, but they appeared to be similar in all other respects. Regardless of the positions of their perikarya, they sent thin, varicose dendrites to both the distal and the proximal strata. The slender dendrites 


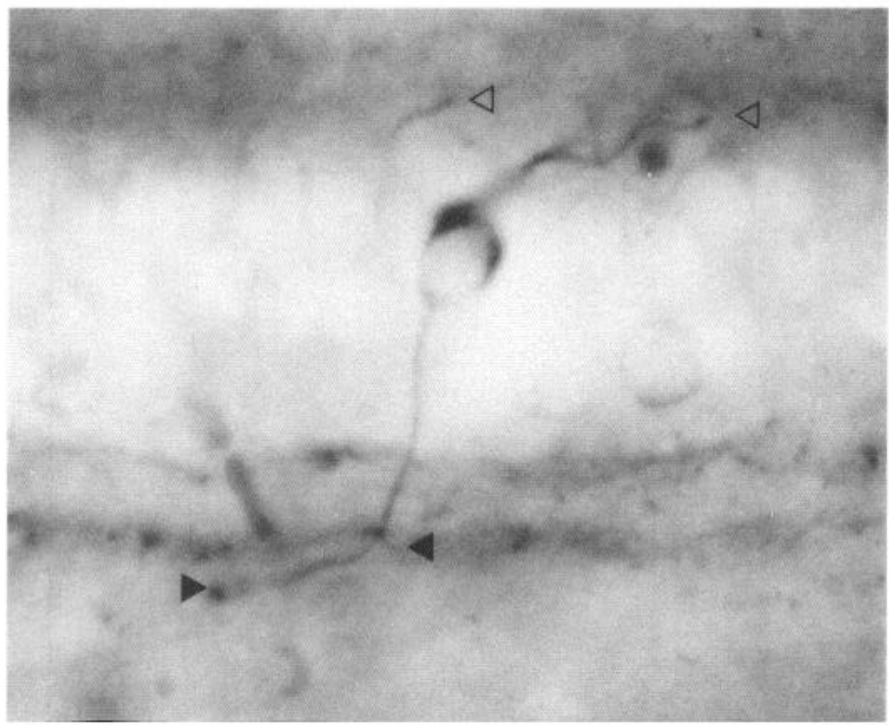

Figure 2. Labeled bipolar cell. A labeled bipolar cell has long, obliquely oriented dendrites in the OPL, and its axon descends to the proximal stratum of the IPL (open triangle). Note the labeled amacrine cell perikaryon and the 2 plexuses of labeled amacrine cell processes $(980 \times)$.

interconnecting the 2 strata were not always as conspicuous as the ones illustrated in Figure 5; some of these dendrites originated from higher-order branches at sites farther from the perikarya. There were no apparent morphological differences between the dendrites in the proximal and distal strata.

The second type of amacrine cell occurred less frequently and was larger than the first type at the same retinal locations (see Figs. $5,6 c, d$ ). The diameters of the perikarya were approximately $10-15 \mu \mathrm{m}$ and increased with eccentricity. The proximal dendrites of the second type were somewhat larger in diameter at their origins than the first type, and no examples of dendrites from the second type running between strata were observed. The dendrites ramified in the same 2 strata of the IPL as did
Table 2. Amacrine cell synapse types by sublamina

\begin{tabular}{llllll} 
& $\begin{array}{l}\text { Pre- } \\
\text { synaptic } \\
\text { bipolar }\end{array}$ & $\begin{array}{l}\text { Pre- } \\
\text { synaptic } \\
\text { amacrine }\end{array}$ & $\begin{array}{l}\text { Post- } \\
\text { synaptic } \\
\text { bipolar }\end{array}$ & $\begin{array}{l}\text { Post- } \\
\text { synaptic } \\
\text { amacrine }\end{array}$ & $\begin{array}{l}\text { Post- } \\
\text { synaptic } \\
\text { ganglion }\end{array}$ \\
\hline $\begin{array}{l}\text { Distal } \\
N\end{array}$ & 17 & 20 & 5 & 21 & 8 \\
$\quad$ Total & $24 \%$ & $28 \%$ & $7 \%$ & $30 \%$ & $11 \%$ \\
$\%$ type & $46 \%$ & $54 \%$ & $15 \%$ & $62 \%$ & $24 \%$ \\
$\begin{array}{l}\text { Proximal } \\
N\end{array}$ & 6 & 31 & 4 & 22 & 14 \\
$\quad$ Total & $8 \%$ & $40 \%$ & $5 \%$ & $29 \%$ & $18 \%$ \\
$\%$ type & $16 \%$ & $84 \%$ & $10 \%$ & $55 \%$ & $35 \%$ \\
\hline
\end{tabular}

The conventions here are the same as in Table 1, but the labeled amacrine cells are described, instead. Using $46 \%$ as the dividing line, the synapses in the distal and proximal sublaminae are compared. Using the statistical method described in the text, we showed that the types of processes postsynaptic to the labeled ones were not significantly different. Amacrine cell processes received most of the synapses from the labeled processes. A significant proportion of their output was directed to retinal ganglion cell dendrites, but bipolar cell axons received very few synapses. The only statistically significant difference between sublaminae was in the processes that were presynaptic to the labeled ones. In the distal sublamina nearly half the inputs were from bipolar cell axons, but there were far fewer in the proximal sublamina.

the first one, however, and it was not always possible to distinguish the 2 types of amacrine cell dendrites in the electron microscope. Thus, the synaptic connections in the figures and in Tables 2 and 3 include both types of labeled amacrine cells.

The laminar distribution of labeled amacrine cell synapses irrespective of type is illustrated in Figure 7. There were very few synapses between 0 and $15 \%$ or between $75 \%$ and $100 \%$ of the distance from the INL to the GCL. These 2 regions of low density roughly correspond with the first and fifth strata defined by classical techniques. There were also 2 peaks of high synapse density, one from approximately $20-40 \%$ and the other from approximately $55-75 \%$. These strata containing most of the labeled dendrites would be classified as the second and fourth
Figure 3. Labeled bipolar cells. In these camera lucida drawings, the solid lines are the OPL, and the dashed lines are the boundaries of the IPL (scale bar, $10 \mu \mathrm{m})$. The cell in $a$ is one of the rare cells whose dendrites contact cones directly above their perikarya. The other, more typical dendrites run obliquely through the OPL to contact a subpopulation of cones. The cells in the upper drawings $(a, b)$ appear to contact only 1 cone, but the others below $(c)$ contact 2 or 3 cones. Note the specialized terminals on the dendrites and the terminals of the axons in the fifth stratum of the IPL.
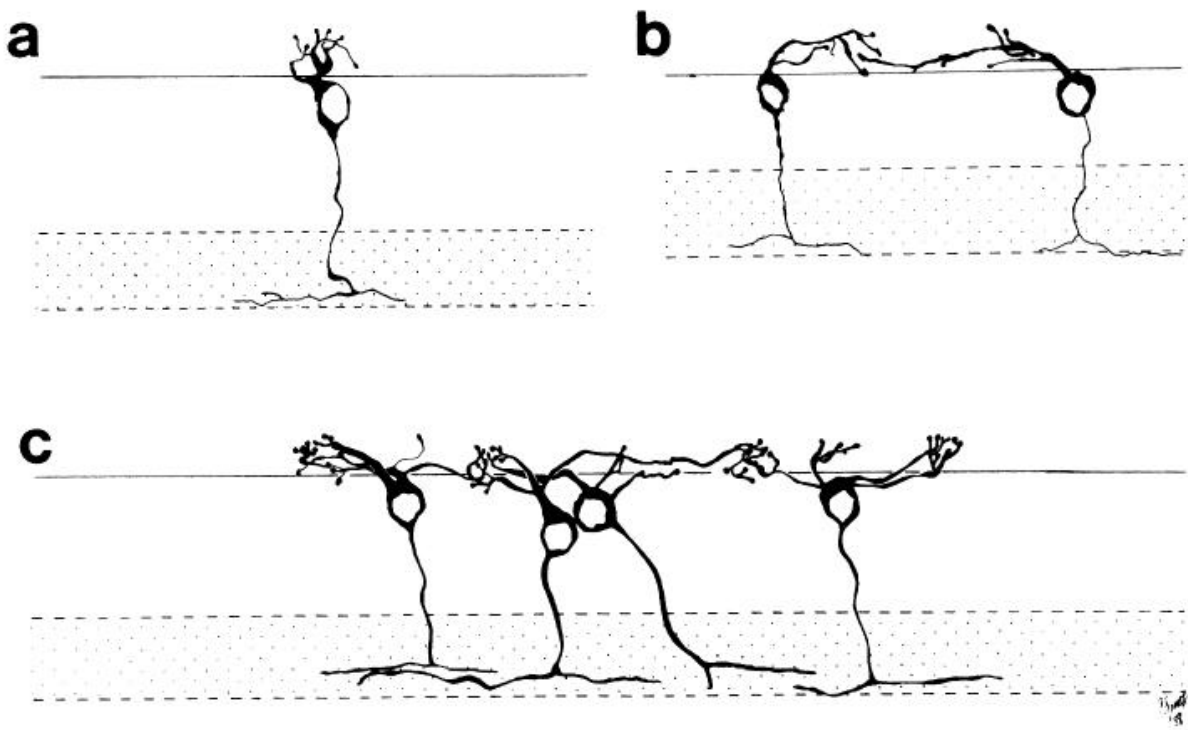


\begin{tabular}{|c|c|c|c|c|c|}
\hline & $\begin{array}{l}\text { Pre- } \\
\text { synaptic } \\
\text { bipolar }\end{array}$ & $\begin{array}{l}\text { Pre- } \\
\text { synaptic } \\
\text { amacrine }\end{array}$ & $\begin{array}{l}\text { Post- } \\
\text { synaptic } \\
\text { bipolar }\end{array}$ & $\begin{array}{l}\text { Post- } \\
\text { synaptic } \\
\text { amacrine }\end{array}$ & $\begin{array}{l}\text { Post- } \\
\text { synaptic } \\
\text { ganglion }\end{array}$ \\
\hline \multicolumn{6}{|l|}{ Distal } \\
\hline$N$ & 45 & 118 & 11 & 68 & 54 \\
\hline Total & $15 \%$ & $40 \%$ & $4 \%$ & $23 \%$ & $18 \%$ \\
\hline$\%$ type & $28 \%$ & $72 \%$ & $8 \%$ & $41 \%$ & $24 \%$ \\
\hline \multicolumn{3}{|c|}{ Total inputs 163} & \multicolumn{3}{|c|}{ Total outputs 133} \\
\hline & \multicolumn{2}{|l|}{$55 \%$} & \multicolumn{3}{|c|}{$45 \%$} \\
\hline \multicolumn{6}{|c|}{$\begin{array}{l}\text { The conventions are the same as in Table } 1 \text {. The sample for this table includes } \\
\text { additional labeled amacrine cell synapses whose depth in the IPL was not determined. } \\
\text { The labeled processes made roughly the same number of synapses as they received, } \\
\text { as expected for typical dendrites of amacrine cells. Note that the cells containing } \\
\text { G6-Gly-IR interacted with bipolar cell axons at } 19 \% \text { of all their synapses. Most } \\
\text { of these contacts were inputs from bipolar cell axons to labeled amacrine cell } \\
\text { processes. }\end{array}$} \\
\hline
\end{tabular}

strata of the IPL. There were also a few synapses in the third stratum between the 2 peaks. The same sample of synapses was divided into distal and proximal sets using $46 \%$ as the border between the 2 , and the types of synapses they contain were compared in Table 2. The output synapses (i.e., synapses from labeled to unlabeled cells) were very similar in the 2 strata. When compared by $\chi^{2}$ analysis, the outputs were not significantly different $\left(\chi^{2}=3.46, p=0.175\right)$. However, the difference between the input synapses (i.e., synapses from unlabeled to labeled cells) in the 2 strata was highly significant $\left(\chi^{2}=21.04, p=0.0001\right)$. There were roughly equal numbers of inputs from amacrine cell dendrites and bipolar cell axons in the distal sublamina, and $31 \%$ of all synapses of labeled cells found there were with bipolar cells. In the proximal sublamina, on the other hand, there were far fewer inputs from bipolar cells.

Table 3 lists data from Table 2 and 148 additional synapses, all those whose polarity could be determined. The rare gap junctions made by labeled processes and contacts between 2 labeled processes (not illustrated) were omitted. The labeled cells received approximately the same number of synapses $(55 \%)$ as they made $(45 \%)$. The labeled amacrine cell processes received a substantial proportion of their input (28\%) from bipolar cell axons. All except 1 of these inputs occurred at typical ribbon synapses like that illustrated in Figure 8 . The majority of the inputs to labeled amacrine cells $(72 \%)$ came from unlabeled amacrine cells like those illustrated in Figure 9; contacts between labeled cells were extremely rare. Some of the amacrine cell processes presynaptic to the labeled processes had relatively electron-dense cytoplasm (see Fig. 10). Approximately half the outputs of labeled amacrine cells $(51 \%)$ were directed to amacrine cells (see Fig. 11). There were also, however, a considerable number of synapses ( $41 \%$ of the outputs) onto processes clearly or tentatively identified as retinal ganglion cell dendrites (see Figs. 12, 13). There were also a few synapses ( $8 \%$ of the outputs) from labeled dendrites onto unlabeled bipolar cell axons (see Fig. 14).

\section{Discussion}

\section{Radioimmunoassays of peptides in retinal extracts}

The radioimmunoassay results indicated that all the immunoreactive peptides in macaque retinal extracts were derived from proCCK. The negative results with antiserum 1611 indicated that progastrin was not present (Rosenquist and Walsh, 1980).

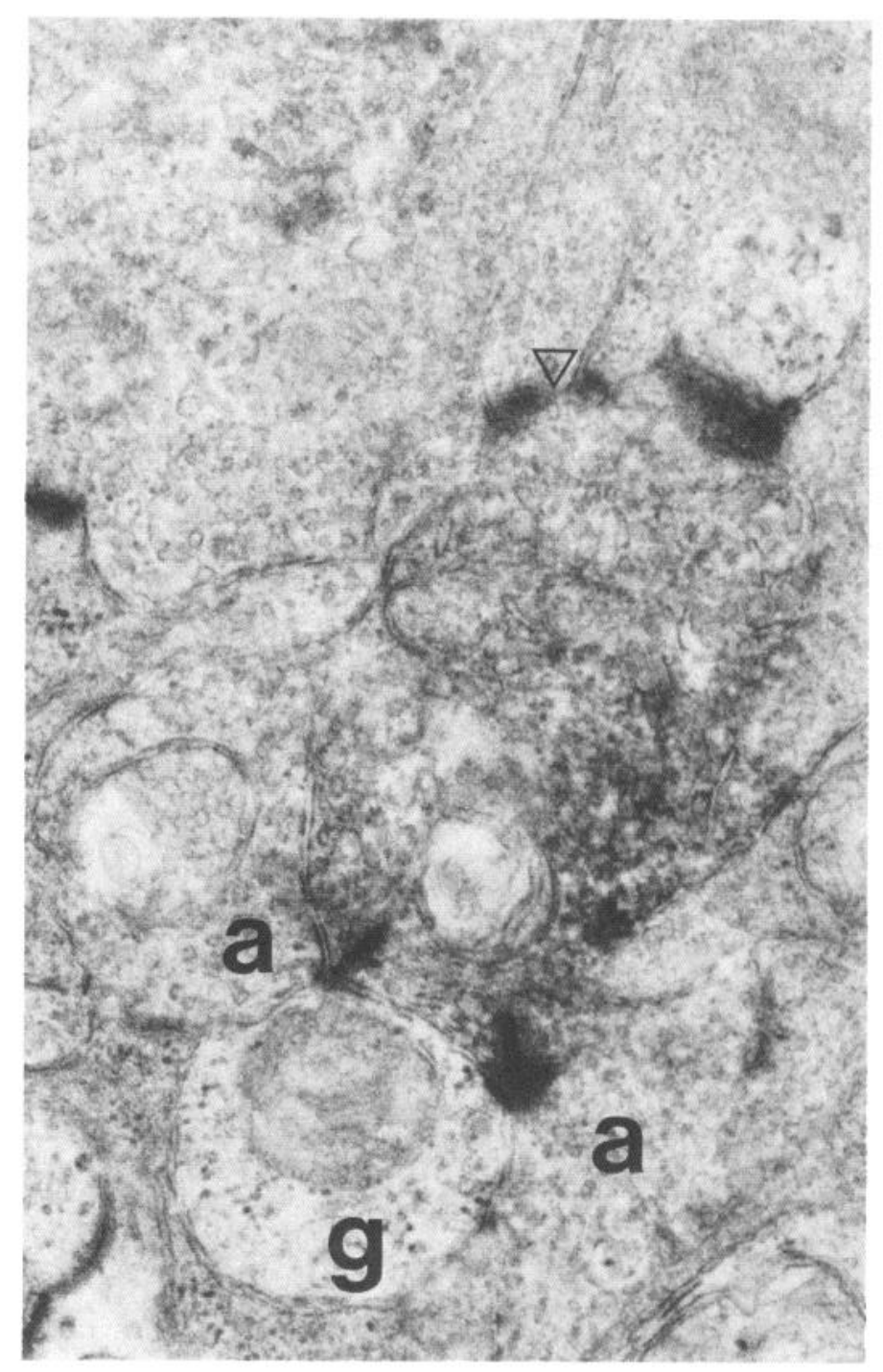

Figure 4. Bipolar cell axonal synapses. A labeled bipolar cell is presynaptic to a retinal ganglion cell dendrite $(g)$ and 2 amacrine cell processes $(a)$ at 2 ribbon synapses. The labeled bipolar cell also receives a synapse from an unlabeled amacrine cell above $(40,000 \times)$. The open triangle indicates the direction of synaptic transmission.

In this respect, the macaque retina resembled most other regions of the primate CNS in which products of proCCK are the only members of this "family" of related peptides present (reviewed by Rehfeld, 1985). The immunoassay methods were designed to detect all the products of proCCK that contain the sequence that imparts biological activity. The 3 radioimmunoassays were able to detect that sequence without covalent modification (8207), after the cleavage of the arginine residues (8237), or after the conversion of the carboxyl terminal glycine to an amide group (5135).

All the molecular forms containing that sequence were likely to be extracted by the 2-step procedure employed in this study. It has been shown previously that the small, amidated forms were extracted in the boiling water and that larger forms were extracted in the acetic acid (reviewed by Rehfeld, 1985). An early study of the molecular forms of mammalian retinal peptides related to $\mathrm{CCK}$ concluded that $\mathrm{CCK} 8$ was the predominant form (Eskay and Beinfeld, 1982), but the methanol extraction 


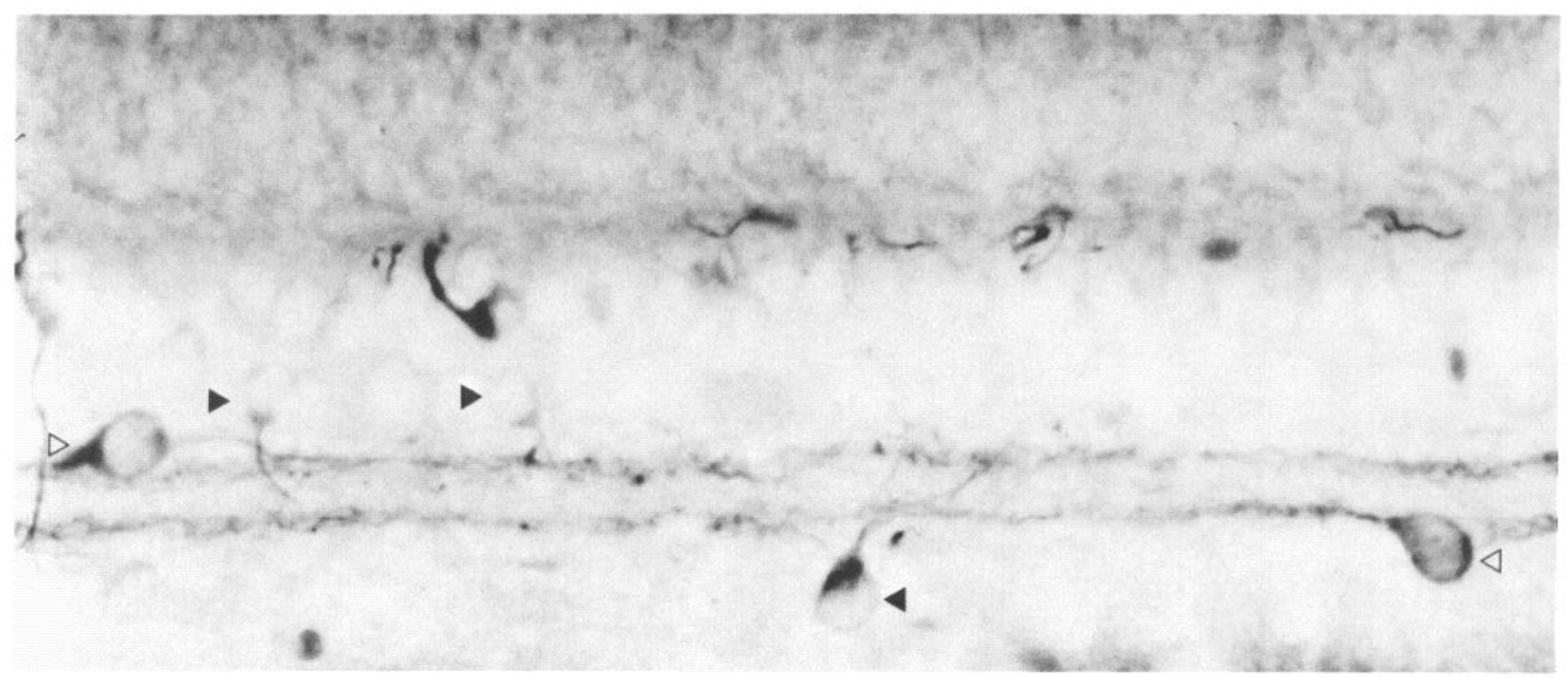

Figure 5. Labeled amacrine cells. The solid triangles indicate the perikarya of small, bistratified labeled amacrine cells. Two examples of the larger, unistratified cells are indicated with open triangles. Approximately equal numbers of both types of perikarya were found in the INL and GCL.

technique used in that study has been shown to yield only small forms such as CCK8 and not the larger or more basic forms detected in more recent studies with acetic acid extracts.

\section{Molecular forms derived from proCCK}

The molecular forms of CCK in the macaque retina were unusual because of the abundance of precursors. However, the same antisera to G6-Gly and G6-Gly-Arg-Arg that were used in the present study also detected large amounts of peptides with extensions at the carboxyl terminus in other mammalian retinas (Aldrich et al., 1987). Previous studies of proCCK-derived peptides in other regions of the mammalian CNS have usually found much higher concentrations of active, amidated forms relative to precursor forms extended at the carboxyl terminus (Beinfeld, 1985; Sugano et al., 1985; Jonsson et al., 1986; Han et al., 1987). An exception is the cerebellum, which has been reported to contain higher concentrations of carboxyl-terminal-extended forms of CCK than amidated forms (Han et al., 1987).

A previous immunocytochemical study of gastrin-secreting endocrine cells that also used these antisera suggests a possible explanation. Immunoreactive G6-Gly was found only in immature granules, where peptide processing occurs, but not in mature granules storing the amidated product (Funata et al., 1989). If the metabolism of proCCK in neurons were similar, the prevalence of precursors relative to active forms in the retina might indicate that the rates of CCK turnover are higher there than in most other parts of the CNS. This finding is consistent with the localization of this peptide in bipolar cells, which are thought to release their neurotransmitter tonically.

Six major peptides derived from proCCK were detected by gel-filtration chromatography and the region-specific radioimmunoassays. Large-molecular-weight forms eluting near the void
Figure 6. Labeled amacrine cells. $a, b$, Camera lucida drawings show the small, bistratified type of labeled amacrine cell (scale bar, $10 \mu \mathrm{m}$ ). The dendrites form 2 plexuses in the second and fourth strata of the IPL. The processes connecting the 2 plexuses were not usually as conspicuous as the ones illustrated here; typically, they were thinner and originated from more distal dendrites. The larger, unistratified type is shown in $c$ and $d$.

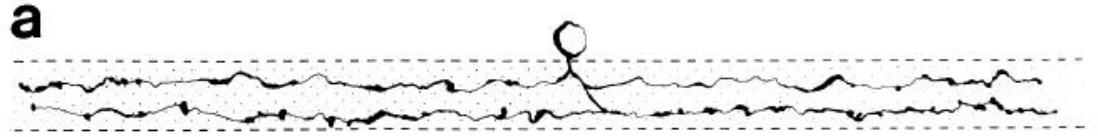

b

C
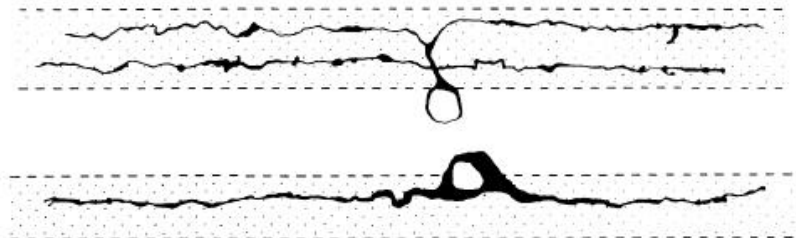

d

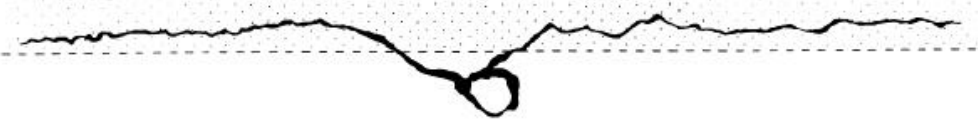


Amacrine Cell Synapses

20

10

0

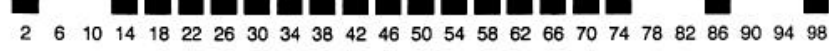

\% Depth in IPL

Figure 7. Distribution of labeled synapses. The distribution of all types of labeled amacrine cell synapses is plotted as a function of depth in the IPL with 0 at the inner nuclear layer and $100 \%$ at the ganglion cell layer. Note the 2 peaks centered at approximateiy $30 \%$ and $65 \%$. volume were detected with all 3 antisera. While these peptides were similar in size, they were clearly different in structure. The G6-Gly-IR form was found in the water extract, and the G6Gly-Arg-Arg-IR form was found in the acid extract. In addition to this difference in solubility, the 3 forms must have also been different in the structure of their carboxyl termini. Previous studies have shown that antiserum 5135 only recognizes amidated forms, that antiserum 8237 only recognizes forms with glycine at the carboxyl terminus, and that antiserum $8207 \mathrm{rec}-$ ognizes only forms with longer carboxyl-terminal extensions (Sugano and Yamada, 1985; Sugano et al., 1985). Most larger products of proCCK previously reported have been found in acid extracts, as was the case with the G6-Gly-Arg-Arg-IR form, but a large water-extractable form like the one observed with the G6-Gly antiserum has been described previously in the hippocampus (reviewed by Rehfeld, 1985). A very large form of proCCK similar to these has been described previously in primate tissue and named "component I" (Rehfeld, 1987).

The only intermediate-sized form was detected with the antiserum to G6-Gly, and it appeared to be similar to one described previously in the brain (Beinfeld, 1985). A small peptide was detected with the antiserum to amidated CCK, and it appears to be identical to CCK8, as reported previously in the retina

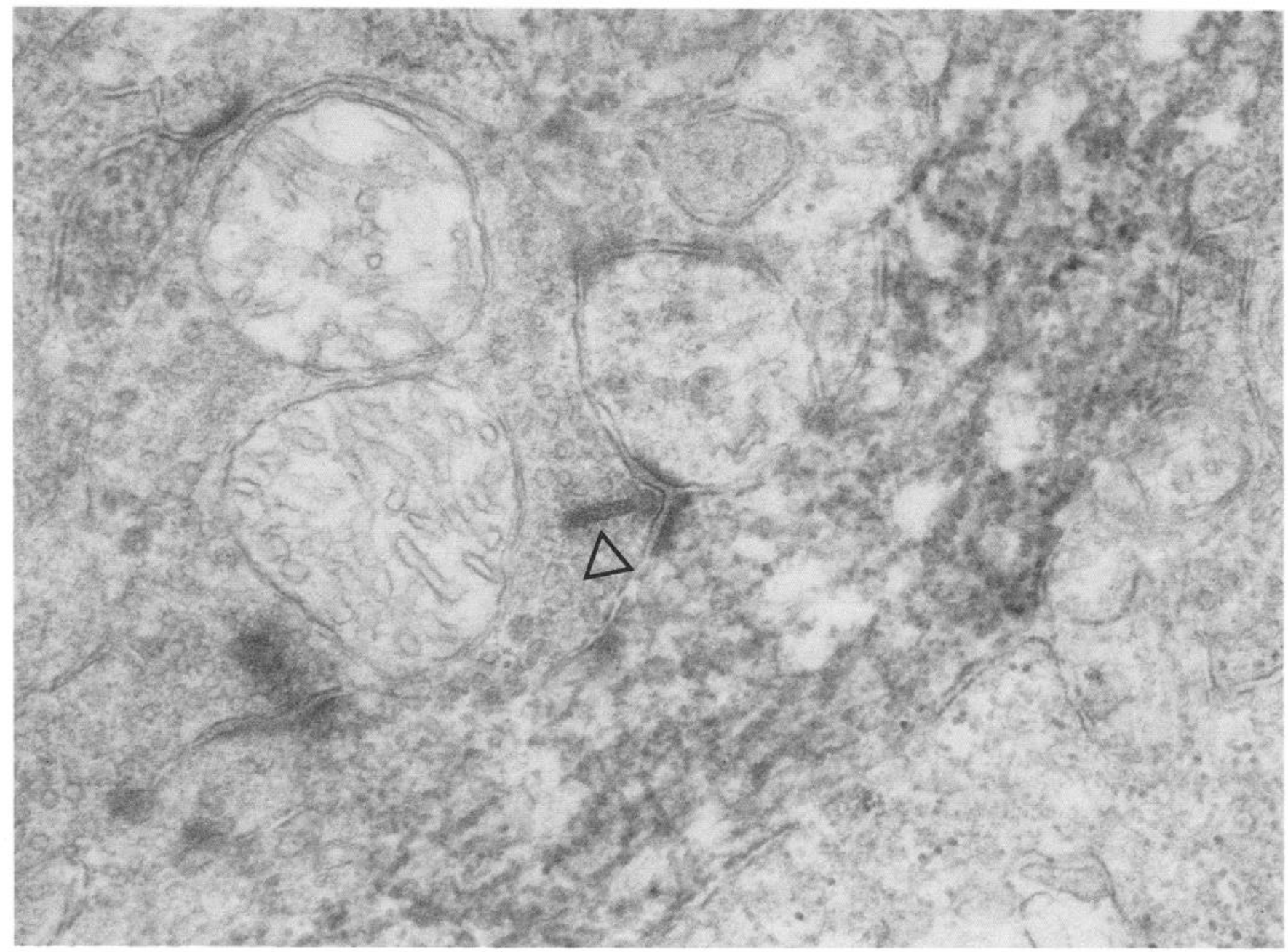

Figure 8. Bipolar cell presynaptic. A labeled amacrine cell dendrite receives a synapse from a bipolar cell axon at a ribbon synapse (54,000 $\times$ ). The open triangle indicates the direction of synaptic transmission. 


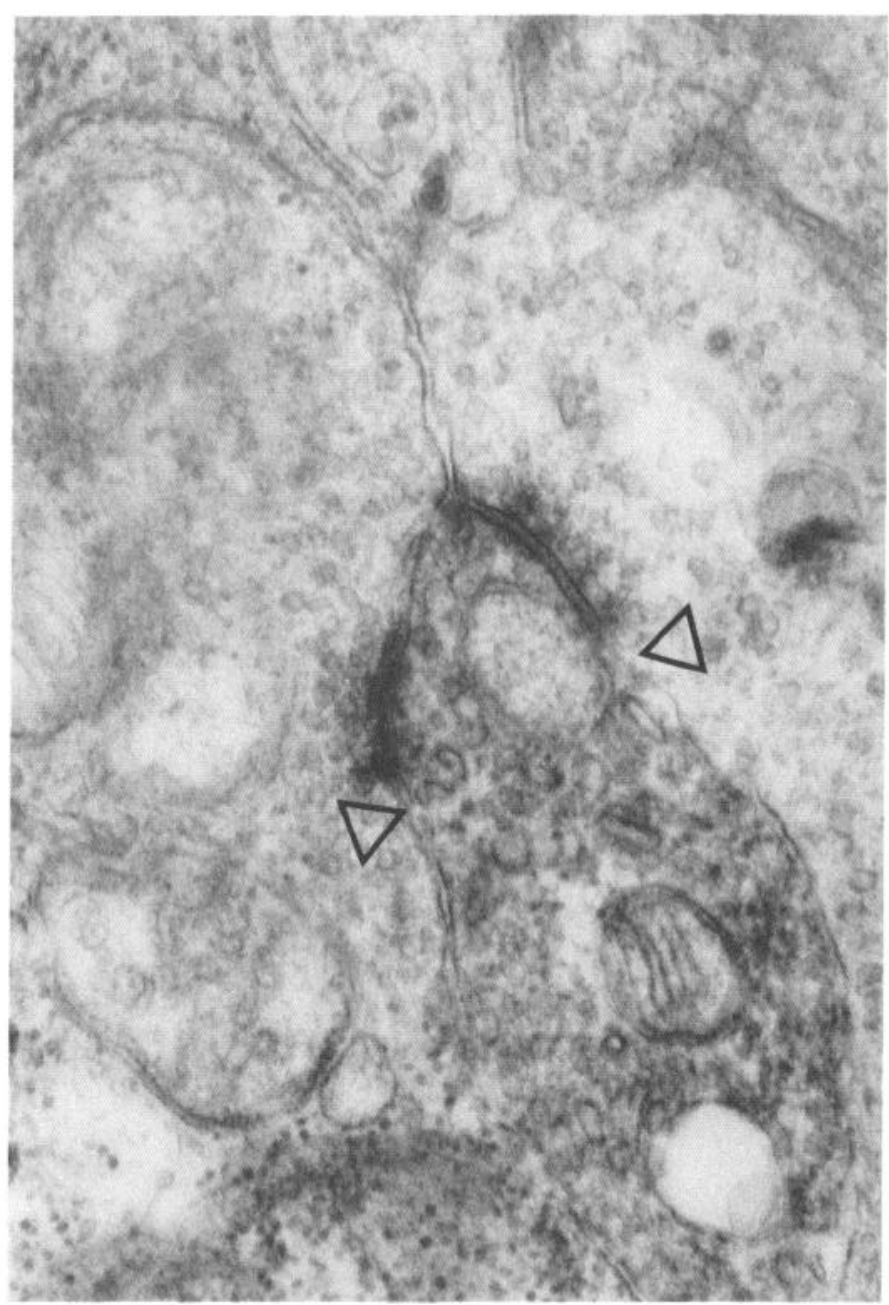

Figure 9. Amacrine cells presynaptic. A labeled amacrine cell process receives 2 inputs from electron-lucent amacrine cells $(50,000 \times)$. The open triangles indicate the direction of synaptic transmission.

(Yamada et al., 1981; Eskay and Beinfeld, 1982). In addition, a small G6-Gly-Arg-Arg-IR form was found, and it appeared to be similar to the small carboxyl-terminal-extended form described previously in the brain (Beinfeld, 1985).

\section{Identification of the labeled bipolar cells}

One type of neuron labeled with G6-Gly antisera was clearly a bipolar cell. The perikarya were small, elongated vertically, and found in the distal 2 rows of the INL. Their axons also made ribbon synapses in the IPL characteristic of bipolar cells (Dowling and Boycott, 1966). Their long, obliquely oriented dendrites resembled those of the short-wavelength-cone-selective type described previously in the macaque, and their axons ramified in the same stratum of the IPL (Mariani, 1984a). The critical feature for identifying the short-wavelength bipolar cells in Golgi preparations was their selective dendritic contacts with a subpopulation of cones, and, in this respect, the G6-Gly-IR bipolar cells were virtually identical to the type labeled by Mariani (1984a). Unlike other primate bipolar cells (reviewed by Mariani, 1984b), these dendrites never contacted 2 adjacent cones, and there were 3 cones on average between the cones contacted. The distances between the cones contacted corresponded well with the known spacing of the short-wavelength

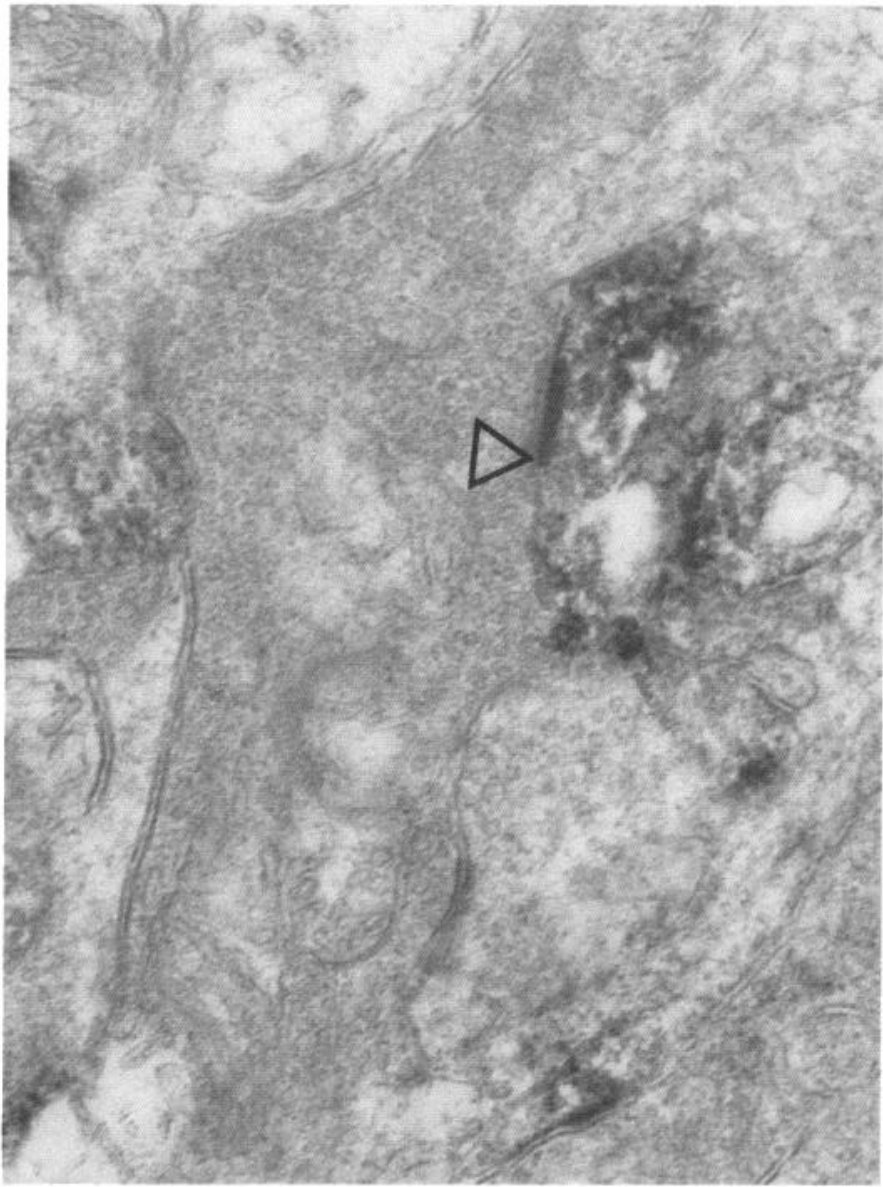

Figure 10. Amacrine cell presynaptic. A labeled amacrine cell process receives a synapse from a relatively electron-dense amacrine cell process that resembled the glycinergic type. Note that there are many other labeled processes nearby $(40,000 \times)$. The open triangle indicates the direction of synaptic transmission.

cones (de Monasterio et al., 1985; Ahnelt et al., 1987). The axons of both types also terminated exclusively in the most proximal stratum of the IPL (Mariani, 1984a). Because the entire population of G6-Gly-IR bipolar cells appeared to be labeled, detailed studies of their contributions to the spatial resolution function of the short-wavelength system will be possible in future experiments.

The most likely candidate for a colocalized neurotransmitter in these bipolar cells is glutamate, which has been localized to all, or at least a large percentage, of bipolar cells in primates (Lam et al., 1982; Brandon and Lam, 1983; Sarthy et al., 1986; Massey, 1990). Bipolar cells of the macaque have also been shown to contain immunoreactive aspartate aminotransferase (Mosinger and Altschuler, 1985). Another bipolar cell neurotransmitter candidate, glycine, is less likely to be colocalized with G6-Gly-IR because glycine-positive bipolar-cell terminals are most numerous in strata 3 and 4 , but not stratum 5 , of the IPL (Lam et al., 1982; Frederick et al., 1984; Marc and Liu, 1985; Hendrickson et al., 1988). The techniques used previously all label large numbers of bipolar cells, and, because G6-Gly-IR bipolar cells only comprise a small percentage of the total, they could easily have been missed if they had not been labeled. Thus, it is still uncertain whether these bipolar cells 


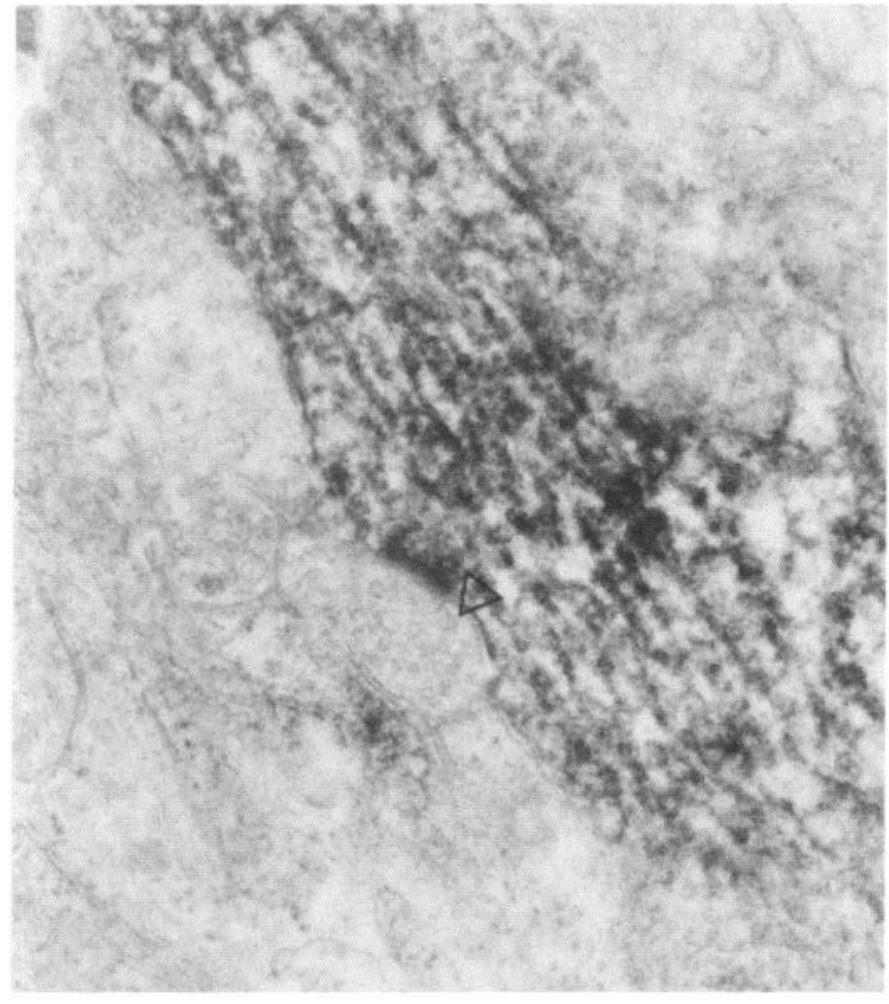

Figure 11. Amacrine cell postsynaptic. A large, labeled amacrine cell process is presynaptic to an unlabeled amacrine cell process $(45,000 \times)$. The open triangle indicates the direction of synaptic transmission.

containing G6-Gly-IR also contain a conventional neurotransmitter.

\section{Identification of the labeled amacrine cells}

There were 2 types of labeled amacrine cells, and both had dendrites in strata 2 and 4 of the IPL. The unstratified cells with the larger perikarya resembled types A13 and A14 described recently by the Golgi method (Mariani, 1988). The bistratified cells with smaller perikarya and more slender dendrites were far more common. Cells like these have been described using the Golgi method in vertical sections (Polyak, 1941) and in whole isolated retinas, in which they were classified as the A8 type (Mariani, 1988).

While there were some similarities between the "starburst" or cholinergic amacrine cells of the macaque and the smaller G6-Gly-IR amacrine cells, they were clearly 2 morphologically distinct types (Mariani and Hersh, 1988; Rodieck, 1989). Although both types ramified in strata 2 and 4 of the IPL, the cholinergic cell was unistratified, and the G6-Gly-IR cell was bistratified. Also, the dendrites of the G6-Gly-IR cells did not show the characteristic distal expansions of cholinergic dendrites. Although the G6-Gly-IR cells made more contacts with bipolar cells and ganglion cells than other peptidergic amacrine cells (Marshak, 1989), they did not make as many as the cholinergic cells (Mariani and Hersh, 1988). In addition, the cholinergic cells received a large proportion of their amacrine cell input from other cells of the same type, but synapses between 2 G6-Gly-IR cells, on the other hand, were extremely rare.

Although their processes are found in the same strata, neither type of G6-Gly-IR amacrine cell resembled the glycinergic ama-

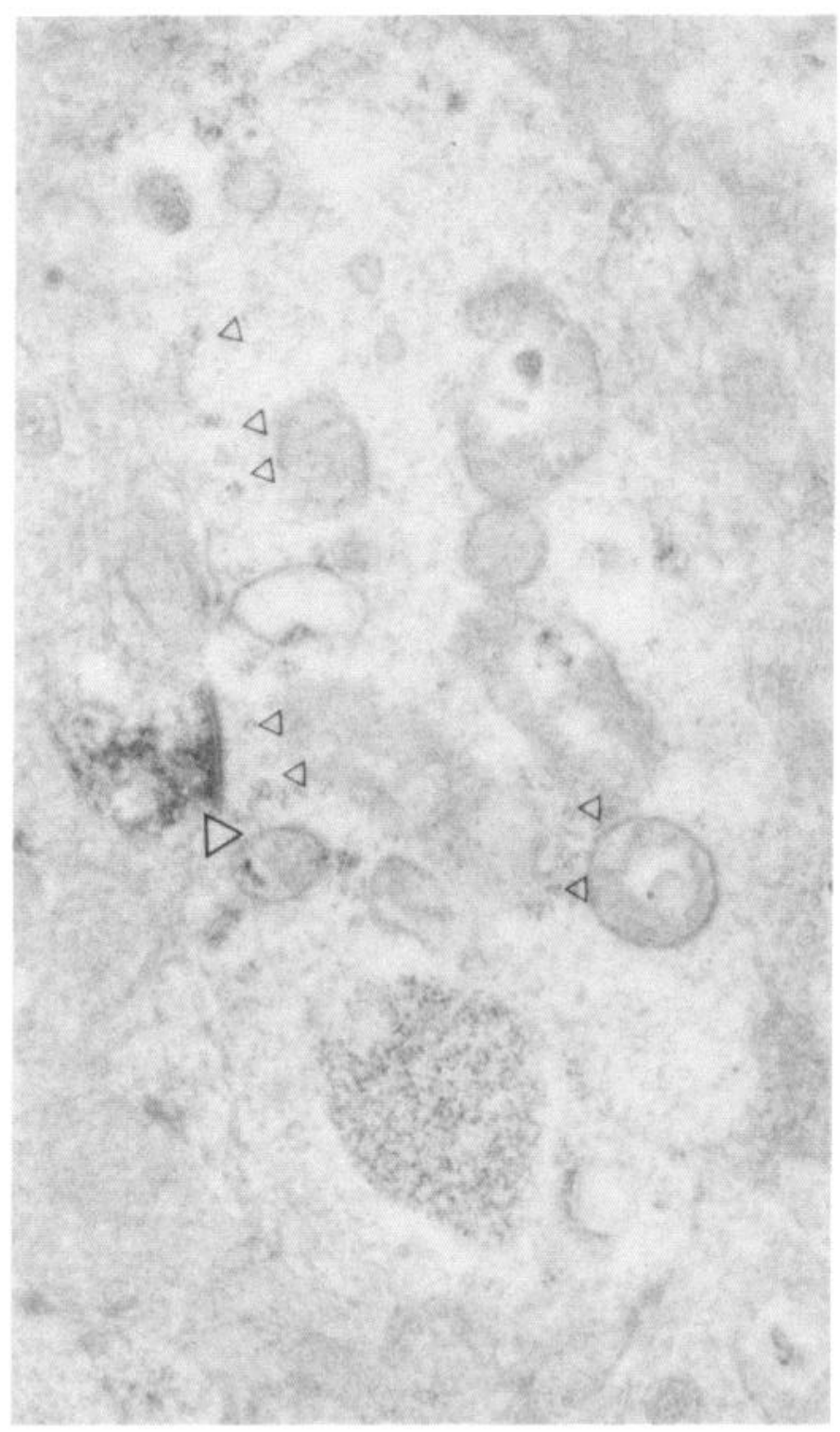

Figure 12. Retinal ganglion cell postsynaptic. A large, proximal retinal ganglion cell dendrite receives an input from a labeled amacrine cell process. This dendrite was identified unequivocally by its ribosomes, which are indicated by small open triangles on $(30,000 \times)$. The large open triangle indicates the direction of synaptic transmission.

crine cells that have been described in the primate retina (Lam et al., 1982; Frederick et al., 1984; Marc and Liu, 1985; Hendrickson et al., 1988). The G6-Gly-IR cells were far more narrowly stratified, had larger dendrite fields, and lacked the lobulated appendages characteristic of glycinergic amacrine cells. Multiple types of primate amacrine cells that contain GABA have also been described (Brandon, 1985; Hendrickson et al., 1985; Nishimura et al., 1985; Mariani and Caserta, 1986; Agardh et al., 1987), but it is unlikely that they contain G6-Gly-IR. Their terminals are most dense in strata 1,3 , and 5 of the IPL, rather than in strata 2 and 4, where the G6-Gly-IR cells ramified. The other amacrine cells in the macaque retina known to contain immunoreactive peptides were also clearly different in their morphology and synaptic connections (Marshak, 1989).

The G6-Gly-IR amacrine cells most closely resembled the cells containing immunoreactive aspartate aminotransferase 


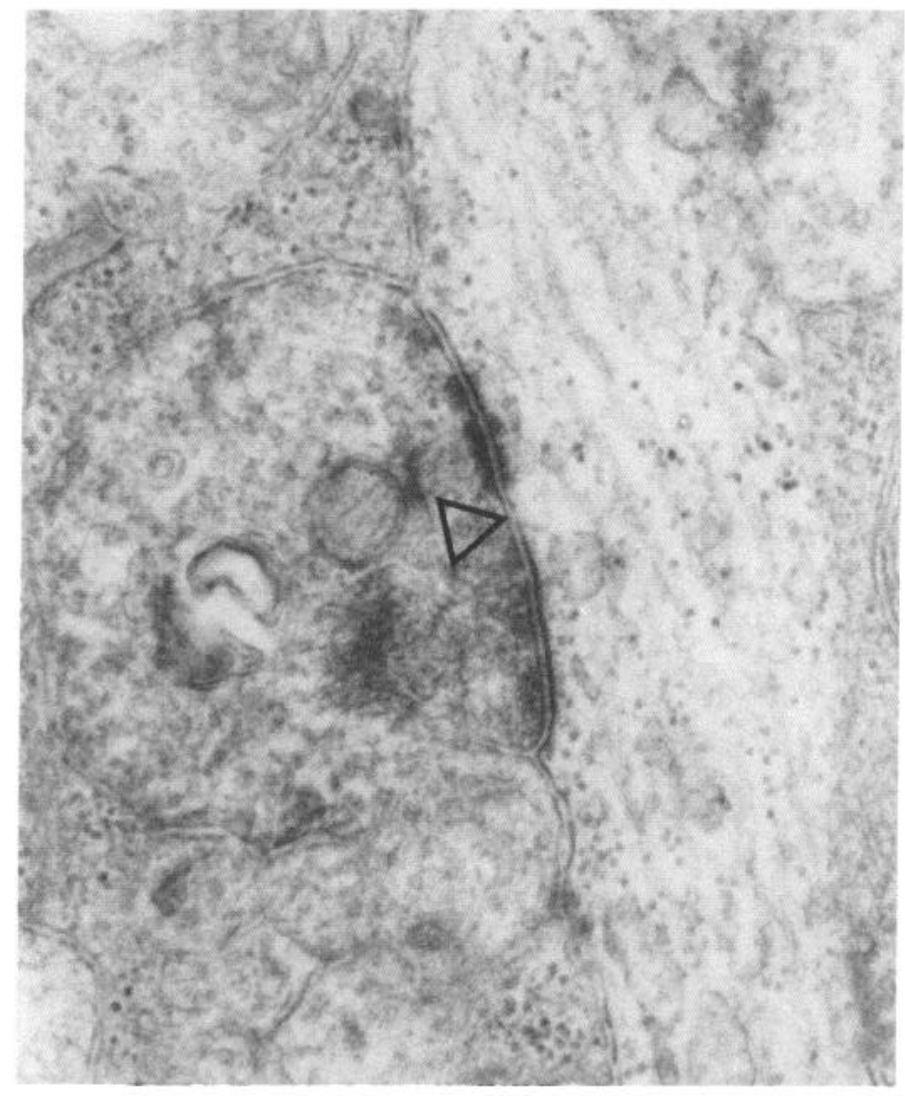

Figure 13. Retinal ganglion cell postsynaptic. Another process postsynaptic to a labeled amacrine cell process was tentatively identified as a retinal ganglion cell dendrite by the absence of presynaptic specializations $(47,000 \times)$. The open triangle indicates the direction of synaptic transmission.

(AAT-IR) (Mosinger and Altschuler, 1985; Sarthy et al., 1986). The AAT-IR terminals were most dense in strata 2 and 4 of the IPL, and their synaptic connections were also similar. Assuming that the profiles "not clearly identifiable as amacrine cell processes" in the study by Mosinger and Altschuler (1985) were ganglion cell dendrites, they received nearly the same number of contacts from AAT-IR and G6-Gly-IR processes. The AATIR amacrine cells made fewer contacts with amacrine cells and more with bipolar cells. These results indicate that G6-Gly and AAT may be colocalized in some, but not in all, instances. There is some controversy about the identity of the neurotransmitter used by AAT-IR cells (Massey, 1990), however, and it remains uncertain whether the G6-Gly-IR amacrine cells also contain a conventional neurotransmitter.

\section{Functions of labeled amacrine cells}

Most of the synapses of the labeled amacrine cells $(63 \%$ of the total) were with amacrine cells. Glycinergic and cholinergic cells are particularly likely to contact G6-Gly-IR amacrine cells because both are common and both ramify most extensively in the same 2 strata of the IPL (Lam et al., 1982; Frederick et al., 1984; Marc and Liu, 1985; Hendrickson et al., 1988; Mariani and Hersh, 1988). The glycinergic amacrine cells are relatively electron dense, and the presynaptic process illustrated in Figure 10 may be an example.

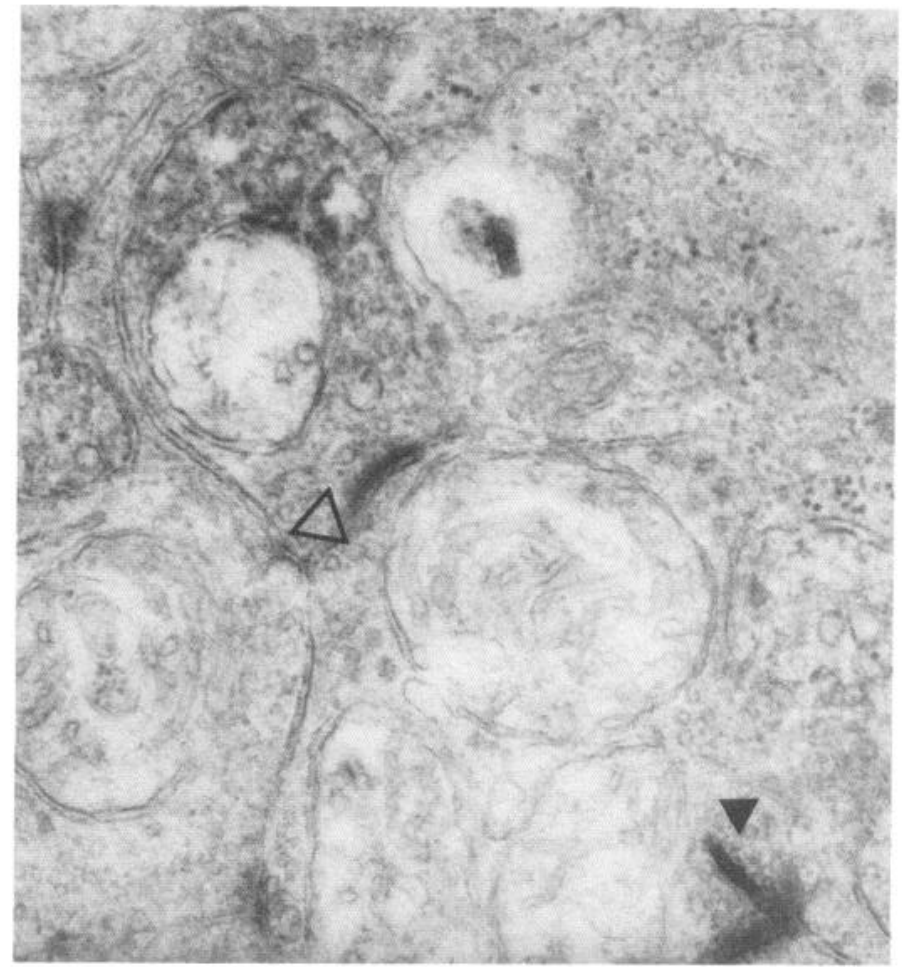

Figure 14. Bipolar cell postsynaptic. A bipolar cell axon that receives a synapse from a labeled amacrine cell process was identified by its synaptic ribbon (solid triangle). The open triangle indicates the direction of synaptic transmission.

The labeled amacrine cells directed $41 \%$ of their output synapses to retinal ganglion cells. Because the strata containing G6Gly-IR dendrites were centered at $30 \%$ and $65 \%$ of the IPL depth, they were likely to contact the "parasol" types, which have been shown to ramify in the second and fourth strata of the IPL (reviewed by Watanabe and Rodieck, 1989).

The G6-Gly-IR amacrine cells also made a substantial number of synapses ( $19 \%$ of the total) with bipolar cells. The frequency of synapses from labeled amacrine cells onto bipolar cells was similar in both strata (only $8 \%$ of the output synapses). Most of the contacts with bipolar cells were synapses onto the labeled cells, and these accounted for $28 \%$ of their inputs overall. These inputs from bipolar cells were particularly common in stratum 2 of the IPL, where bipolar cells provided $46 \%$ of the input to labeled amacrine cells. It is likely that the presynaptic bipolar cells included the "flat diffuse" type that ramify extensively there (reviewed by Mariani, 1984b; Rodieck, 1988).

The amacrine cells that contained G6-Gly-IR received more inputs from bipolar cell axons than any peptidergic neurons described in the macaque to date (Marshak, 1989), and they directed a considerable proportion of their output synapses to retinal ganglion cells. In this respect, they resemble other amacrine cells thought to contribute directly to visual information processing and differ from amacrine cells that are thought to have only modulatory functions (Masland, 1988). Taken with the result that this peptide has rapid effects on retinal ganglion cell activity (Thier and Bolz, 1985), these anatomical data suggest that CCK may act more like a conventional neurotransmitter than a neuromodulator. Additional physiological studies of CCK's effects on retinal neurons and double-label immu- 
nocytochemical studies to look for conventional neurotransmitters in the cells containing this peptide will be necessary to test this hypothesis.

\section{References}

Agardh E, Ehinger E, Wu J-Y (1987) GABA and GAD-like immunoreactivity in the primate retina. Histochem 86:485-490.

Ahnelt PK, Kolb H, Pflug R (1987) Identification of a subtype of cone photoreceptor, likely to be blue sensitive, in the human retina. J Comp Neurol 255:18-34

Aldrich LA, Takami M, Yamada T (1987) Post translational processing of procholecystokinin in the retina. Invest Ophthalmol Vis Sci [Suppl] 28:353

Beinfeld MC (1985) Peptides in rat brain immunorcactive for the carboxyl terminal extension of cholecystokinin: distribution and chromatography. Peptides 6:857-860.

Bone EA, Rosenzweig SA (1987) Characterization of cholecystokinin receptors in toad retina. Peptides 9:373-381.

Brandon C (1985) Retinal GABA neurons: localization in vertebrate species using an antiserum to rabbit brain glutamate decarboxylase. Brain Res 344:286-295.

Brandon C, Lam DMK (1983) L-Glutamic acid: a neurotransmitter candidate for cone photoreceptors in human and rat retinas. Proc Natl Acad Sci USA 80:5117-5121.

Brecha N (1983) Retinal neurotransmitters: histochemical and biochemical studies. In: Chemical neuroanatomy (Emson PC, ed), pp 85-129. New York: Raven.

Cote GJ, Gould JA, Huang F-C, Gagel RF (1987) Studics of shortterm secretion of peptides produced by alternative mRNA processing. Mol Cell Endocrinol 58:211-219.

de Monasterio FM, McCrane EP, Newlander JK, Schein SJ (1985) Density profile of blue-sensitive cones along the horizontal meridian of macaque retina. Invest Opthalmol Vis Sci 26:289-302.

Dowling JE, Boycott BB (1966) Organization of the primate retina: electron microscopy. Proc Roy Soc Lond [Biol] 166:80-111.

Eldred W, Zucker C, Karten H, Yazulla S (1983) Comparison of fixation and penetration techniques for use in ultrastructural immunocytochemistry. J Histochem Cytochem 31:285-292.

Eriksen EF, Larsson L-I (1981) Neuropeptides in the retina: evidence for differential topographical localization. Peptides 2:153-157.

Eskay RL, Beinfeld MC (1982) HPLC and RIA of cholecystokinin peptides in the vertebrate neural retina. Brain Res 246:315-318.

Frederick JM, Rayborn ME, Hollyfield JG (1984) Glycinergic neurons in the human retina. J Comp Neurol 227:159-172.

Funata N, Fukayama M, Sugano K, Koike M (1989) Intracellular topography of glycine-extended pro-gastrin-processing intermediates in human antral mucosa: an electron-microscopic immunocytochemical study. J Histochem Cytochem 37:287-292.

Han SP, Allard LR, Beinfeld MC (1987) Peptides in rat brain immunoreactive for the amino terminus of cholecystokinin 33: distribution and chromatography. Biochem Biophys Res Commun 149: 902-907.

Hendrickson A, Ryan M, Noble B, Wu J-Y (1985) Colocalization of ${ }^{3} \mathrm{H}$-muscimol and antisera to GABA and glutamic acid decarboxylase within the same neurons in monkey retina. Brain Res 348:391-396.

Hendrickson A, Koontz M, Pourcho R, Sarthy P, Goebel D (1988) Localization of glycine-containing neurons in the Macaca monkey retina. J Comp Neurol 273:473-487.

Jonsson A-C, Varro A, Dockray GJ (1986) Antibodies to the C-terminus of the cholecystokinin precursor: radioimmunoassay and immunohistochemical studies in adult and developing rat gut. Peptides 8:95-101

Kuljis RO, Karten HJ (1988) Neuroactive peptides as markers of retinal ganglion cell populations that differ in anatomical organization and function. Vis Neurosci 1:73-81.

Kuljis RO, Krause JE, Karten HF (1984) Peptide-like immunoreactivity in anuran optic nerve fibers. $\mathrm{J}$ Comp Neurol 226:222-237.

Lam D-MK, Frederick JM, Hollyfield JG (1982) Identification of putative ncurotransmitters in the human retina. In: The structure of the eye (Hollyfield JG, ed), pp 205-213. New York: Elsevier.

Marc RE, Liu W-LS (1985) ${ }^{3} \mathrm{H}$ glycine-accumulating neurons of the human retina. J Comp Neurol 232:241-260.

Mariani AP (1984a) Bipolar cells in monkey retina selective for the cones likely to be blue-sensitive. Nature 308:184-186.

Mariani AP (1984b) The neuronal organization of the outer plexiform layer of the primate retina. Int Rev Cytol 86:285-320.

Mariani AP (1988) Amacrine cells of the rhesus monkey retina. Invest Ophthalmol Vis Sci [Suppl] 29:198.

Mariani AP, Caserta MT (1986) Electron microscopy of glutamate decarboxylase (GAD) immunoreactivity in the inner plexiform layer of the rhesus monkey retina. J Neurocytol 15:645-655.

Mariani AP, Hersh LB (1988) Synaptic organization of cholinergic amacrine cells in the rhesus monkey retina. J Comp Neurol 267:269280.

Marshak DW (1989) Peptidergic neurons of the macaque monkey retina. Neurosci Res [Suppl] 10:S117-S130.

Masland RH (1988) Amacrine cells. Trends in Neurosci 11:405-410.

Massey SC (1990) Cell types in the retina that use glutamate as a neurotransmitter. Prog Retinal Res 9:399-425.

Mosinger JL, Altschuler RA (1985) Aspartate aminotransferase-like immunoreactivity in the guinea pig and monkey retinas. J Comp Neurol 233:255-268.

Nishimura Y, Schwartz ML, Rakic P (1985) Localization of gammaaminobutyric acid and glutamic acid decarboxylase in rhesus monkey retina. Brain Res 359:351-355.

Osborne NE (1985) Cholecystokinin in the retina of vertebrates. Ann NY Acad Sci 448:157-166.

Osborne NN, Nicholas DA, Cuello AC, Dockray GJ (1981) Localization of cholecystokinin immunoreactivity in amacrine cells of the retina. Neurosci Lett 26:31-35.

Osborne NN, Nicholas DA, Dockray GJ, Cuello AC (1982) Cholecystokinin and substance $P$ immunoreactivity in retinas of rats, frogs, lizards and chicks. Exp Eye Res 34:639-649.

Polyak SL (1941) The retina. Chicago: University of Chicago.

Rehfeld JF (1985) Neuronal cholecystokinin: one or multiple transmitters? J Neurochem 44:1-10.

Rehfeld JF (1987) Preprocholecystokinin processing in the normal human anterior pituitary. Proc Natl Acad Sci USA 84:3019-3023.

Rodieck RW (1988) The primate retina. In: Comparative primate biology, Vol IV, Neurosciences (Steklis HD, ed), pp 203-278. New York: Liss.

Rodieck RW (1989) Starburst amacrine cells of the primate retina. J Comp Neurol 285:18-37.

Rosenquist GL, Walsh JH (1980) Radioimmunoassay of gastrin. In: Gastrointestinal hormones (Glass G, ed), pp 769-795. New York: Raven.

Sarthy PV, Hendrickson AE, Wu J-Y (1986) L-Glutamate: a neurotransmitter candidate for cone photoreceptors in the monkey retina. J Neurosci 6:637-643.

Sugano K, Yamada T (1985) Progastrin-like immunoreactivity in porcine antrum: identification and characterization with region-specific antisera. Biochem Biophys Res Commun 126:72-77.

Sugano K, Aponte GW, Yamada T (1985) Identification and characterization of glycine-extended post-translational processing intermediates of progastrin in porcine stomach. J Biol Chem 260:1172411729.

Thier P, Bolz J (1985) Cholecystokinin in the cat retina. Invest Ophthalmol Vis Sci 26:266-272.

Watanabe M, Rodieck RW (1989) Parasol and midget ganglion cells of the primate retina. J Comp Neurol 289:434-454.

Williams RG, Dimaline R, Varro A, Isetta AM, Trizio D, Dockray GJ (1987) Cholecystokinin octapeptide in rat central nervous system: immunocytochemical studies using a monoclonal antibody that does not react with CGRP. Neurochem Intl 11:433-442.

Yamada T, Brecha N, Rosenquist G, Basinger S (1981) Cholecystokinin-like immunoreactivity in frog retina: localization, characterization, and biosynthesis. Peptides 2:93-97. 